\title{
Architecture of Regol nDalem Mangkubumen
}

\author{
Istiana Adianti ${ }^{1}$ \\ ${ }^{1}$ Department of Architecture, Fakultas Sains dan Teknologi, Universitas \\ Widya Mataram
}

\author{
Article History \\ Received : 03 March 2020 \\ Accepted : 29 March 2020 \\ Published : 24 April 2020
}

\begin{abstract}
nDalem Mangkubumen is a cultural heritage building that was previously planned as the residence of the Crown Prince, the future king of the Yogyakarta Palace. In 1874 nDalem Mangkubumen was established, and only the Crown Prince Sultan Hamengku Buwono VI had lived in this building for 5-7 years. Currently, nDalem Mangkubumen is used as a place for education and residential areas, so that changes in the shape of buildings and land use. The spatial pattern of nDalem Mangkubumen was developed from the spatial layout of traditional Javanese houses. Still, because nDalem was designed for the Crown Prince, its grandeur was almost similar to the Yogyakarta Palace. As in the traditional Javanese house building intended for relatives of the king, there is a high wall or fence that surrounds the residential complex and a guardrail on each zone. Each fence has a gate that functions as an entrance into the courtyard. This study aims to determine the variation of the gate and which affects the appearance of the gate. So that the results of the study can be used as a reference when maintaining the gate in nDalem Mangkubumen or other nDalem which are mostly owned by the Yogyakarta Palace. Research on changes in the shape, size, and model of the gate using descriptive qualitative research methods by searching data in literature and interviews. nDalem Mangkubumen has a gate with a different size and shape, this change in shape is influenced by the location of the gate and the function of the building that is inside.
\end{abstract}

\section{Keywords: Gate, Regol, Seketeng, Ndalem Mangkubumen, Keraton}

\section{Introduction}

The njeron Beteng area is a cultural heritage area where its development is ongoing until now (Sektiadi, 2015). nDalem Mangkubumen, as part of nJeron Beteng is a cultural heritage and is one of nDalem registered as cultural heritage buildings in Yogyakarta in 2010 (Cahyandari et al., 2019). Its position on the west side of the Yogyakarta Palace with the northern, eastern and western boundaries is the Kadipaten village and in the south bordering the Kadipaten Street can be seen in figure 1. nDalem is a building that functions as a dwelling prince or relative of the king, nDalem or dalem itself in Javanese means me or me. Besides, the placement of nDalem was also influenced by political, geographical, and social conditions in which the king gave absolute rights to the owner of nDalem to manage it (Cahyandari et al., 2019;

Correspondence: Istiana Adianti

Department of Architecture, Fakultas Sains dan

Teknologi, Universitas Widya Mataram

E-mail: tinaadianti@gmail.com
Wardani, 2007). Based on the inscriptions that exist nDalem Mangkubumen was founded in 1874, during the reign of Sultan Hamengku Buwono VI. At the beginning of its construction, the Palace will be inhabited by the son of the future Sultan Hamengku Buwono VII, Prince Adipati Anom Hamengkunegoro. After Prince Adipati Anom became king, nDalem was inhabited by his younger brother, Prince Mangkubumi, in 1918. Then underwent several changes in function, and the last functioned as an educational facility until now (Yuniastuti \& Murti, 2019).

Figure 1. Place of nDalem Mangkubumen (Source: re-drawing from google map, Adianti,2020)

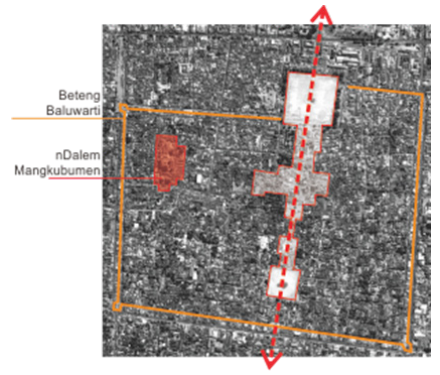


By the basic pattern of Javanese buildings, especially traditional buildings in the Special Region of Yogyakarta, the spatial pattern of nDalem Mangkubumen same as the residential buildings in DIY, only the facilities and grandeur of buildings in nDalem Mangkubumen are almost similar to the Yogyakarta Palace. Therefore nDalem Mangkubumen is often called Keraton Alit. nDalem is a residential complex with an area of about $2000-10,000$ $\mathrm{m} 2$, which is bounded by a $3 \mathrm{~m}$ high fence on the outside of the site (Siti Widayatsari, 2002). The entrance into nDalem is called Gledegan with varying length from the entrance gate or regol to the highway around nDalem. The entrance or gate is not only placed as the main door of nDalem but also inside the nDalem complex to mark boundaries between pages. nDalem Mangkubumen is a representation of the Palace, so the land area is bigger, and the building inside is more than the other $\mathrm{nDalem}$. This affects the number of regol and form found in nDalem Mangkubumen. So it is necessary to know how the variation of gates in NDalem Mangkubumen, what factors influence the different shapes and sizes of the gates in nDalem. The results of this study can be used as a consideration when it will repair or restore the original form of the gate in the environment of nDalem Mangkubumen and nDalem, which are mostly owned by the Yogyakarta Palace. Recalling in 2006, when the earthquake struck Yogyakarta, one of the gates in nDalem Mangkubumen collapsed.

Research with a qualitative descriptive method begins with initial observations on the gates in NDalem Mangkubumen to find out the existence and shape of these gates. Primary data in the form of direct documentation of the gate is then redrawn to facilitate analysis. Secondary data by searching the data both using literature and interviews with sources who have been active in NDalem Mangkubumen at a certain time. The stages of the research began by searching for the spatial layout of Mangkubumen when it functioned as a residence of the king's relatives, then identified the position of the gate and its suitability at this time. If there is a gate that does not exist or has changed its shape due to demands for changes in the function of NDalem, then look for supporting data both from literature, photo documentation, and interviews. From this data, things that affect the shape, size, and model of the gate will be examined.

\section{LITERATURE REVIEW}

\section{Spatial Traditional Javanese Houses}

According to a Javanese vocabulary search (Kartono, 2005), a house derived from the word pomah inhabitants of the house occupies the house, home yard pomahan, by the way, to get married, the word omah-omah means to settle down, to make a home feel. The layout depends on the size of the house and the needs of the family. Joglo type house is the ideal type in the level of a traditional Javanese house. The composition of the Joglo house is divided into three parts namely the meeting room called "pendapa", the living room or space for puppet performances ("ringgit") called "pringgitan", and the backroom called "dalem" or "omah jero" as a room family (Adianti, 2019). In the room, there are 3 "senthong" (rooms), namely "senthong kiwa", "senthong tengah" and "senthong tengen" (Wibowo, 1998). For noble families or relatives of the right and left king of the palace building, there is an elongated building called gandok. In the building complex, there is an entrance gate called regol, as shown in Figure 2. There is an application of the hierarchical principle in spatial planning, the front area is public, and the rear area is private (Djono, 2012).

Figure 2. Spatial Pattern nDalem (Source: Wibowo, 1998)

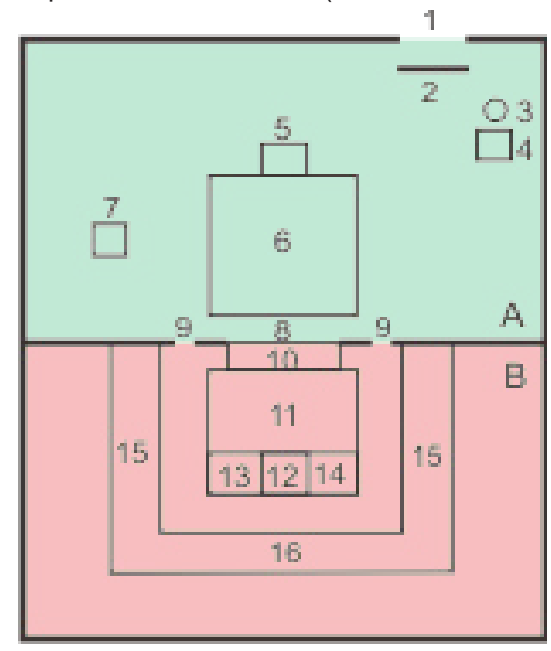

1.Regol, 2.Rana, 3.Sumur, 4.Langgar, 5.Kuncung, 6.Pendopo, 7.Kandang Kuda, 8.Longkangan, 9.Seketheng, 10.Pringgitan, 11.Dalem, 12.Senthong Tengah, 13.Senthong Kanan/Tengen, 14.Senthong Kiri/Kiwo, 15.Gandok, 16.Dapur, A.Front Yard, B.Back Yard 


\section{2. nDalem}

nDalem Spatial Planning has similarities with each other, and this is likely due to the existence of traditions or habits that have developed (Widayatsari, 2002). In that research, it was also revealed that the stratification of $\mathrm{nDalem}$ also affected the structure of his house. The higher the degree and rank of the security system were also tighter. Seen from the existence of a layer of gates in layers in the Palace. The gate located in the front zone can be called regol, while the gate that is in the middle/back zone or that separates the front zone from the middle/ back zone is called Seketeng. Also, the degree and rank also affect the completeness of the facilities available in nDalem.

\section{3. nDalem Mangkubumen}

Based on the inscriptions that are in Mangkubumen, the building began construction in 1874. With the marking of the construction of Sriwerdari building as a family entertainment place. The inscription that shows this is in the Sriwerdari building's ceiling with Latin numbers and Arabic letters. After the Sriwerdari building was then continued by Gedhong Proboyekso as the main building of nDalem Mangkubumen, which began in 1976 and completed in 1877. The function of nDalem Mangkubumen was originally used for the residence of the crown prince of Sultan Hamengku Buwono VI named prince Adipati Anom or Pangeran Pati for 5-7 years or ended in 1912. Then after Prince Adipati Anom became Sultan Hamengku Buwono VII, until 1918, it was occupied by Prince Mangkubumi (younger brother of Prince Adipati Anom). From 1918 to 1928, nDalem Mangkubumen was occupied by Prince Juminah / Prince Buminoto, and then nDalem Mangkubumen was left empty until 1942. It was again occupied in 1948 by the family of General Sudirman until the war ended in 1949. From 1949 to 1975, the nDalem Mangkubumen building was used as a place of education until 1942. by the Faculty of Medicine at Gadjah Mada University, and in 1982 it is used by Widya University Mataram until now (Yuniastuti \& Murti, 2019)

Mangkubumen nDalem spatial pattern is a combination of parallel linear and zoning patterns. The parallel linear pattern that occurs is a linear pattern of three lines with the SouthNorth axis with the main orientation towards the South. The building from south to north (middle linear line) is occupied by the main buildings, namely the Banjar Andhap, Regol Cemeng, Pendapa Ageng, Gedhong Inggil, Pringgitan, and Prabayekso. The west side linear line is occupied by supporting functions such as the Mosque, Pakaryan, Pagongan, Patehan, relatives' houses, Besalen, and supporting wasps. Whereas the east linear line contained the banquet hall, relatives' houses, Bangsal Wetan Alit, and Dapur Ageng. As for zoning, nDalem Mangkubumen is divided into four areas, namely the outer front, front, middle, and rear zone.

Figure 3. Spatial Pattern nDalem Mangkubumen (Source: Yuniastuti, 2010)

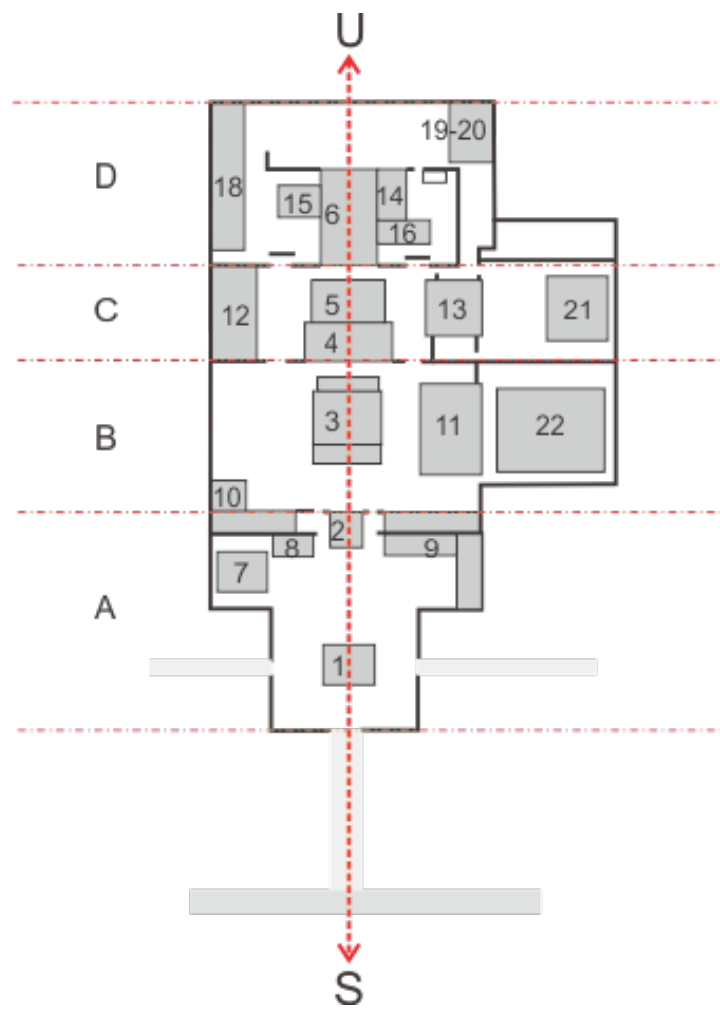

1.Bangsal Banjar Andap, 2. Regol Cemeng, 3.Pendapa Ageng, 4.Gedhong Inggil, 5.Pringgitan, 6.Dalem Prabayekso, 7.Masjid, 8.Pakaryan, 9.Kandang Kereta, 10.Gedong Gangsa, 11.Gedung Perjamuan, 12. Hunian Kerabat, 13. Gedhong ljem, 14. Hunian istri Adipati Anom, 15. Bangsal Alit Kilen, 16. Bangsal Alit Wetan, 17.Pawon Alit, 18.Besalen, 19-20.Pawong Ageng, 21.Bangsal Sriwedari, 22.Gedhongan
A. Outer Front Zone
B. Front Zone
C. Middle Zone
D. Rear Zone 
Table 1. Typology and Changes in Function of Main Buildings in nDalem Mangkubumen (Source: Yuniastuti, 2010 \& Adianti, 2020)

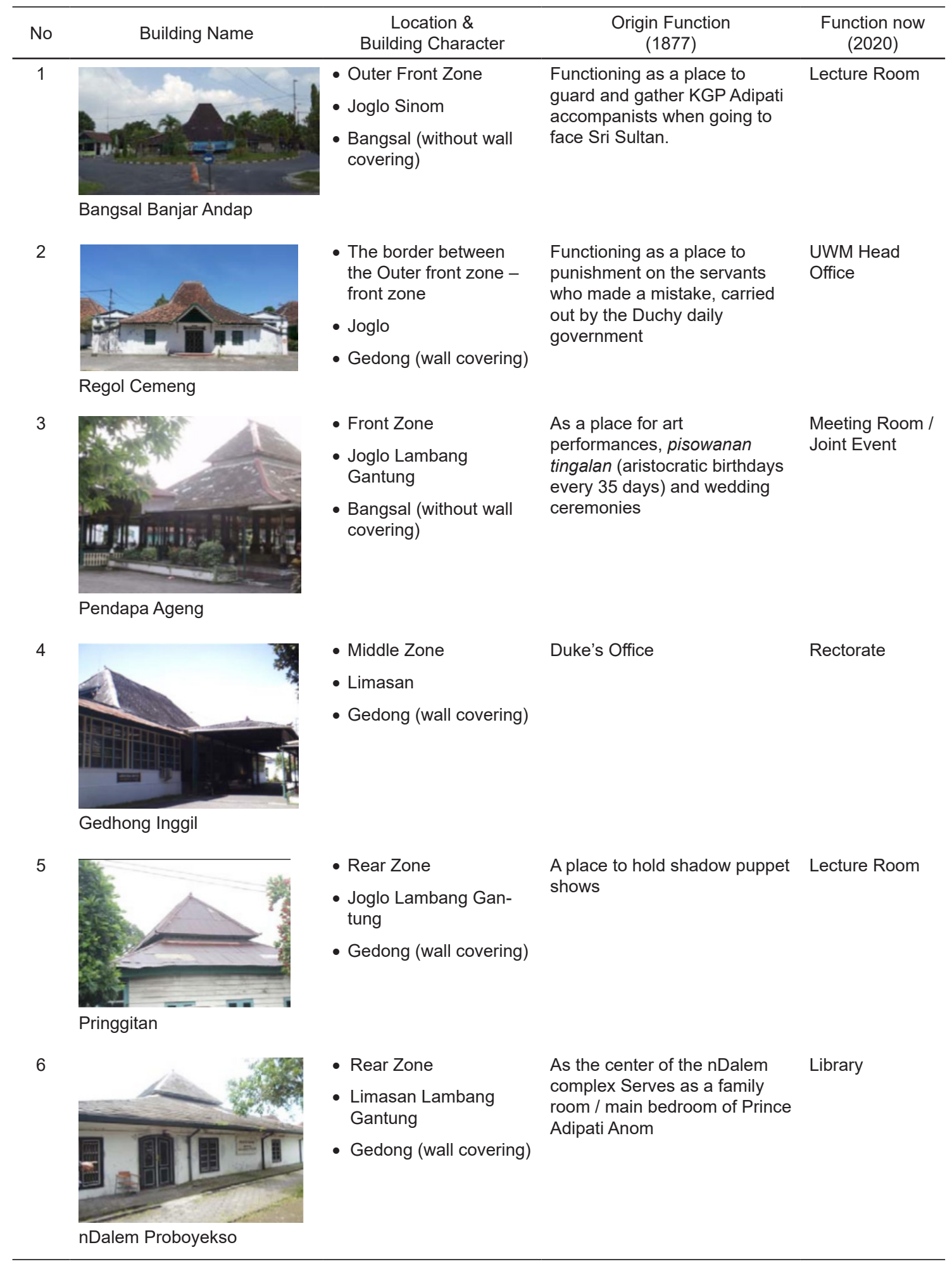




\section{RESULTS AND DISCUSSION}

nDalem Mangkubumen currently functions as an educational center for Widya Mataram University, SD Tumbuh 3, and Tedjokusuman Kindergarten as well as being used as a settlement. Citizens' settlements in the Mangkubumen nDalem complex are descendants or relatives of courtiers who had previously served in nDalem Mangkubumen. nDalem Mangkubumen is surrounded by a 3 $\mathrm{m}$ high fence to mark the complex. According to Nur'aini, the 2019 fence is the primary territory to show authority in managing the area within the fence/fort. Even to demarcate the area inside NDalem Mangkubumen, there is also a fence attached to the boundary gate.
So the fence inside the complex forms a yard or zoning. There are two names for the Gate, namely Regol and Seketeng. Regol is a gate that is located in the outer front zone and the front zone, while Seketeng is a gate that is located at the border of the front and middle zone, the middle zone, and the rear zone. Regol function is a fence for the entrance and exit of people for guests who use vehicles or not (Triyadi et al., 2012). There are still some gates in NDalem Mangkubumen that have been preserved according to the original, but there are some that have changed shape, even left untreated or damaged. If seen from Figure 3 Spatial layout of Mangkubumen and then traced in the field, the existence of the gate or regol is explained in Table 2 below:

Table 2. Condition of the Gate of Mangkubumen nDalem (Source: Adianti, 2020)

\begin{tabular}{|c|c|c|c|c|}
\hline No & Gate Photo & Location & Amount & Condition \\
\hline 1 & & Outer Front Zone & $\begin{array}{l}3 \text { pieces (west, } \\
\text { south, east) }\end{array}$ & Well maintained, there is an iron door \\
\hline 2 & & Outer Front Zone & 1 piece & $\begin{array}{l}\text { Well-maintained, the color changes on the } \\
\text { walls to light yellow and the gate serves as } \\
\text { a buffer roof }\end{array}$ \\
\hline 3 & & Outer Front Zone & 1 piece & $\begin{array}{l}\text { Well maintained, from the information in } 1974 \text {, } \\
\text { the form is still maintained like this. }\end{array}$ \\
\hline 4 & & Outer Front Zone & $\begin{array}{l}2 \text { pieces (east } \\
\text { and west) }\end{array}$ & $\begin{array}{l}\text { Well maintained, there is a little ornament on } \\
\text { the ring balk from wood material in green- } \\
\text { yellow paint color }\end{array}$ \\
\hline & & & & There is a door hinge, but the door is gone. \\
\hline 5 & & Front Zone & $\begin{array}{l}2 \text { pieces (east } \\
\text { and west) }\end{array}$ & Well maintained \\
\hline 6 & & $\begin{array}{l}\text { The border } \\
\text { between Front }\end{array}$ & $\begin{array}{l}2 \text { pieces (east } \\
\text { and west) }\end{array}$ & $\begin{array}{l}\text { The east side is changing shape, and the } \\
\text { shutter is removed }\end{array}$ \\
\hline & & Zone & & $\begin{array}{l}\text { the west side still maintains its original } \\
\text { condition }\end{array}$ \\
\hline 7 & & Middle Zone & 1 piece & $\begin{array}{l}\text { Not maintained, the ornament above the gate } \\
\text { was removed by force }\end{array}$ \\
\hline 8 & & Middle Zone & 1 piece & Not maintained \\
\hline 9 & & Middle Zone & 1 piece & Well maintained \\
\hline
\end{tabular}


10

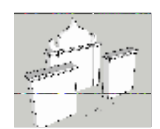

11

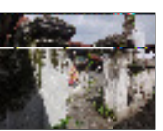

12

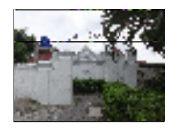

13
Rear Zone

Rear Zone

The border between Middle

Zone - Rear Zone

Rear Zone

1 piece
1 piece

1 piece

2 pieces and west)
Not maintained

Not maintained, the ornament on the shutter was forcibly removed

(east Well maintained, there is ornament when on the Rana.

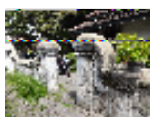

Not maintained

Based on the identification of the gate conditions above, the gate in the front zone outside the front zone and the condition is still maintained, even though two gates have changed shape due to function requirements. The gate is gate number 4 , which originally had a door leaf that has now been removed for practical reasons. Gate number 6 on the east side experienced a large change in openings due to reasons of ease of vehicle access. The condition of the gate is due to periodic maintenance by the University of Widya Mataram. Seketeng in nDalem Mangkubumen has two variations of shapes, those that have shuttered and those that do not add shutter. The shutter is a curtain with the same material as the gate where the position is behind or in front of the gate.

Table 3. Physical Features of nDalem Mangkubumen Gate (Source: Adianti, 2020)

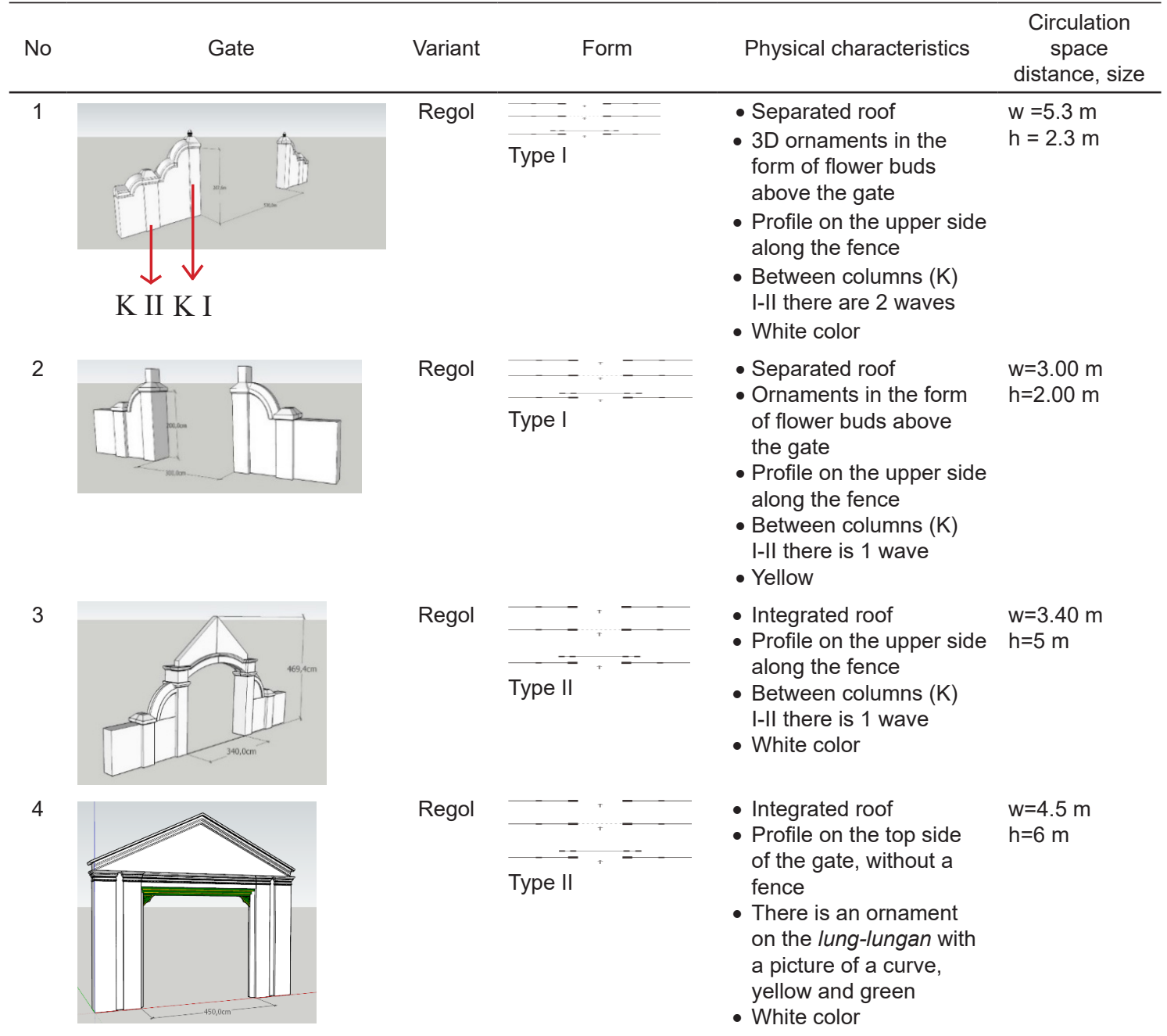


5
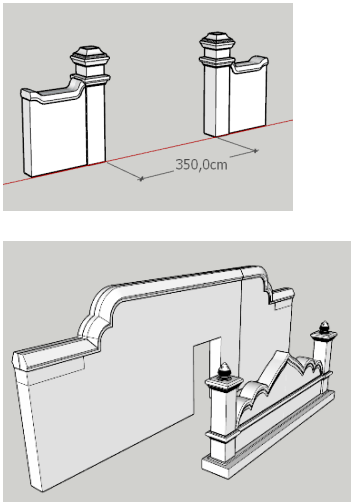

7

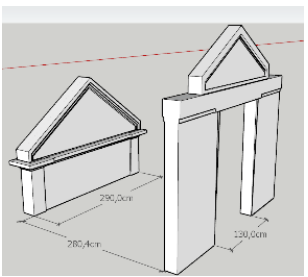

8

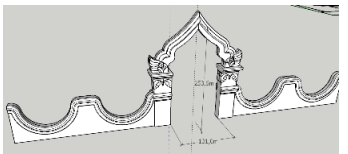

9

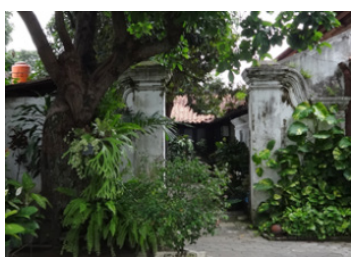

10

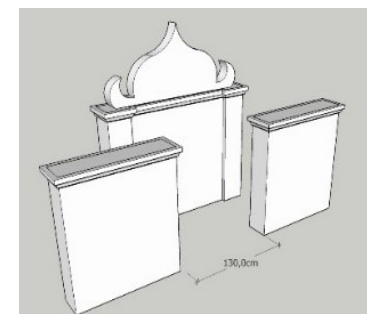

11

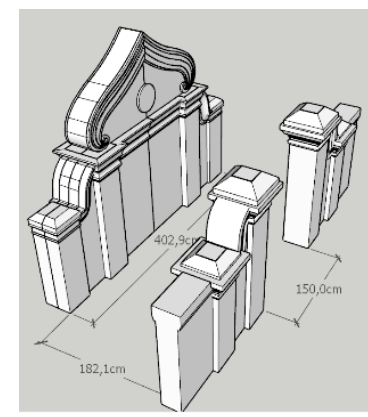

Regol

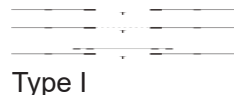

Seketeng with Rana

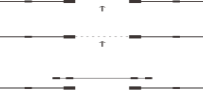

Type III

Seketeng with Rana

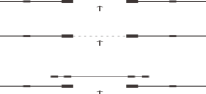

Type III
- Separated roof

- Profile on the upper side along the fence

- There is an only column I

- White color

- Integrated roof

- Profile on the upper side of the gate along the fence.

- White color

- Shutter at both ends has a 3d ornament in the form of a flower bud

- Shutter shape wave combination and triangle on the top side

- Integrated roof

- Profile on the upper side of the gate along the fence.

- White color

- Shape the triangle shutter on the top side

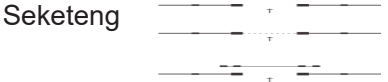

Type II

Integrated roof

- Profile on the upper side along the fence

- There is an ornament on the column and continues to the roof

- The corrugated fence is used to place potted plants

- White color

seketeng

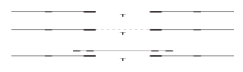

Type I

Separated roof

- Profile on the upper side along the fence

- There is an only column

- White color

seketeng

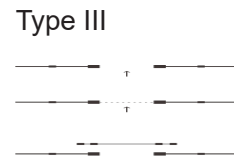

- The roof is not fused

- Profile on the upper side along the fence

- Without prominent columns

- White color

- Shutter, at the top of the combination of triangles and tapered on the outside.

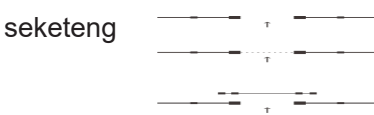

Type III
- Separated roof

- Profile on the upper side of the gate along the fence.

- Between columns (K) I-II there is 1 wave

- White color

- Shutter shape wave combination and triangle on the top side

- There is a $3 d$ ornament on the top side of the shutter, but the condition is gone $\mathrm{w}=3.5 \mathrm{~m}$

$\mathrm{h}=2.5 \mathrm{~m}$

$w=1.30 \mathrm{~m}$

$\mathrm{h}=2.30 \mathrm{~m}$

distance to

Rana $=2.80 \mathrm{~m}$

w rana $=5.80 \mathrm{~m}$

$\mathrm{t}$ rana $=2.2 \mathrm{~m}$

$\mathrm{w}=1.30 \mathrm{~m}$

$\mathrm{h}=2.0 \mathrm{~m}$

distance to

RAna $=2.80 \mathrm{~m}$

w rana $=2.90$

h rana $=2.20$

$\mathrm{w}=1.30 \mathrm{~m}$

$\mathrm{h}=2.80 \mathrm{~m}$

$\mathrm{h}=2.40 \mathrm{~m}$

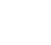


12

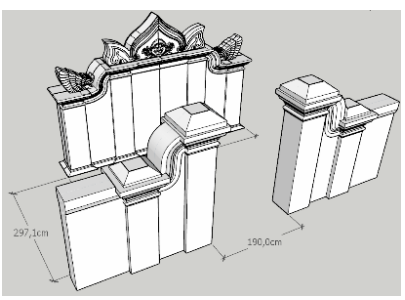

seketeng

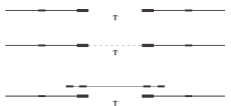

Type III
- Separated roof

- Profile on the upper side of the gate along the fence.

- Between columns (K)

I-Il there is 1 wave

- White color

- Shutter shape wave combination and triangle on the top side

- There is a $3 \mathrm{~d}$ ornament on the upper side of the shape of a kemamang (when) shutter, bird and animal head

- Separated roof

- Profile on the upper

side along the fence

- There is only column I

-White color $w=1.90 \mathrm{~m}$

$\mathrm{h}=2.40 \mathrm{~m}$ distance to

Rana $=3.00 \mathrm{~m}$

$w$ rana $=5.00 \mathrm{~m}$

h rana $=3.00 \mathrm{~m}$
13

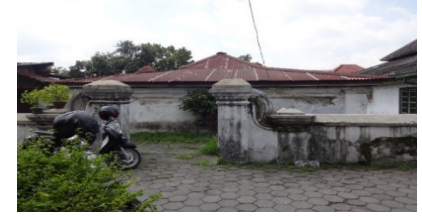

seketeng

Type I $w=1.90 \mathrm{~m}$ $\mathrm{h}=1.60 \mathrm{~m}$

Based on the type of nDalem Mangkubumen gate, if it is positioned in the nDalem area, it can be seen as follows:

Figure 4. Gate at nDalem Mangkubumen (Source: Adianti, 2020)

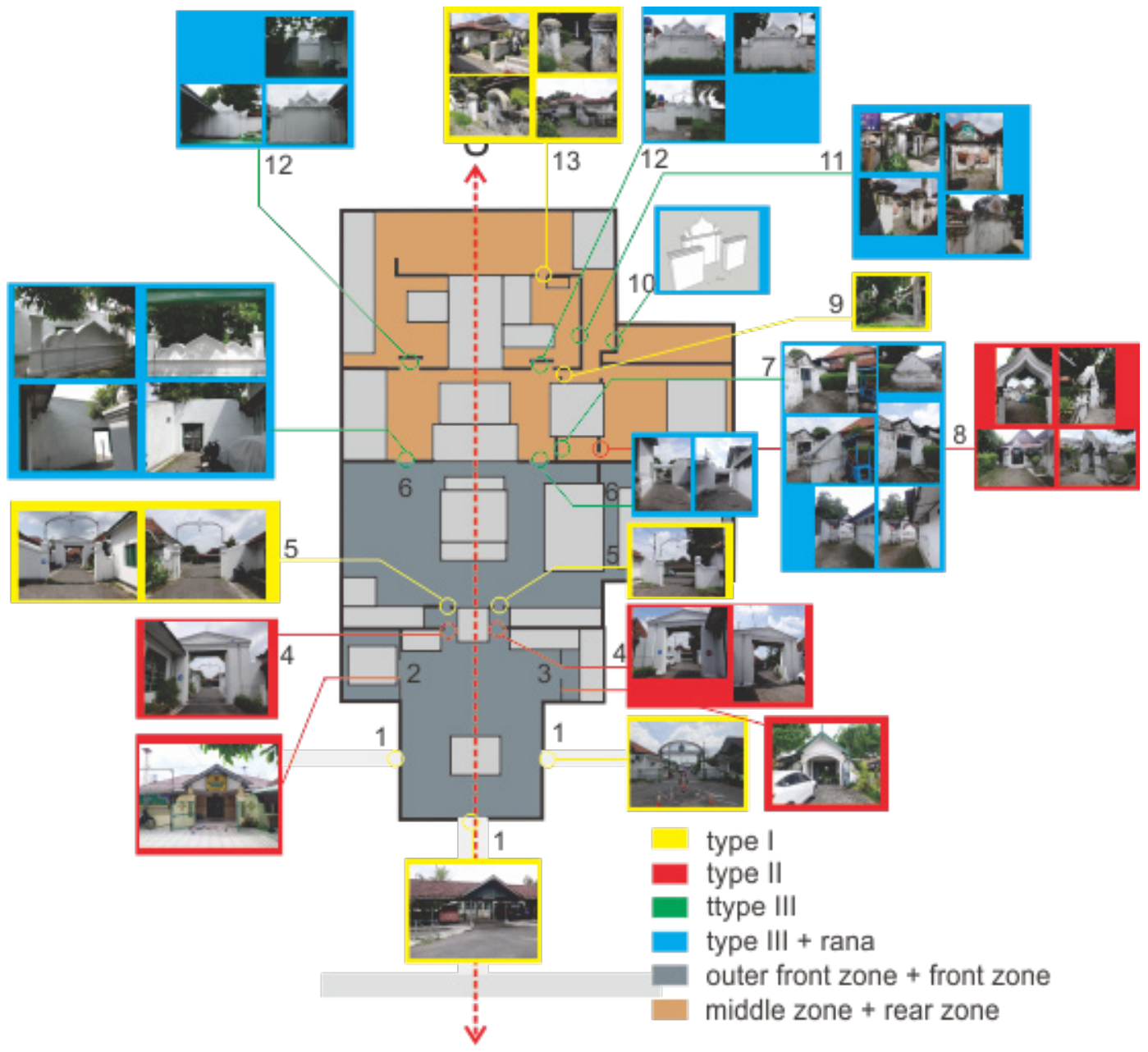


Referring to the gate position based on its zoning, the front zone outside the gate opening width (circulation space) is around $3.00 \mathrm{~m}-5.3$ $\mathrm{m}$. The width consideration is because the outer front zone is very general, namely that anyone must go through this zone to be able to enter the next zone. The existence of buildings in this zone can also describe who is in this area, Banjar Andap, as a gathering place for duchy employees and as a preparation for employees to accompany when the Crown Prince travels and the mosque as a public facility that can be used together. The two buildings reinforce that in the outer front zone, intrusion with outsiders (public) is possible in this area as well as circulation space for transportation modes in the form of horse-drawn carriages. The type of gate in this zone is predominantly simpler in the presence of columns, walls without ornamentation are only profiles on either side (type I). Except for the outer gate, there is a $3 d$ ornament in the form of a flower bud on the top of the gate. Changes in shape and size are on the boundary line between the outer front zone and the front zone, where the height of the gate is the highest compared to the other gates (figure 5) in NDalem Mangkubumen and the gate at the gate even though the current condition of the door is gone and the presence of a lung on the upper side. The placement of this gate is between Regol Cemeng buildings, so the west-east side has the same shape (symmetrical).

Figure 5. Gate between outer front zone and front zone (Source: Adianti, 2020)

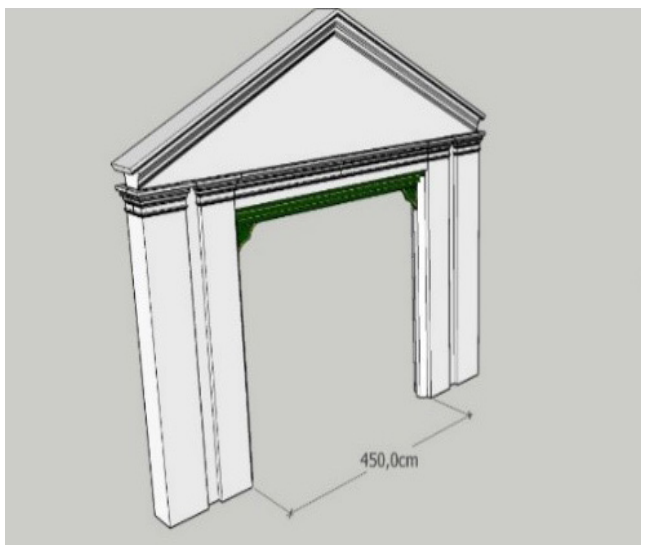

The front zone does not have a gate in the area, except the gate between the zones. The front zone is the area between the outer front zone and the middle zone, and this area is for anyone who is a guest of the crown prince. In the area bordering the outer front zone, the gate circulation space is $3.5 \mathrm{~m}-4.5 \mathrm{~m}$ wide, so it is possible for horse-drawn carriages and groups of people to still pass through it. However, bordering the middle zone, the size of the circulation space narrows to $1.3 \mathrm{~m}$, and there is a shutter or barrier behind the gate as a visual and physical barrier. Changes in the size of the circulation room are due to the middle zone is a private zone, and as a barrier that vehicles are not allowed to enter the middle zone. The shape of the gates in this area also still adjusts to the outer front zone, forming the column with a wall without ornament.

The middle zone is a semi-private zone because it is only intended for relatives of the king. The gates in this area are placed on two sides with the same bay, using a shutter or barrier placed behind the gate (type III). The circulation space width of $1.3 \mathrm{~m}$ shows that only two people can walk side by side, while the gate distance with the shutter is $2.8 \mathrm{~m}$. The gate in this area is called sketeng, and the shape of the seketeng is varied and has a dynamic impression with the presence of ornament combine in the form of a triangle and curve. As in the gate that leads to the Sriwedari ward, the gate uses ornament placed in the left and right column, and the beams that ride above the column are formed more dynamically (figure 6). Sriwedari Ward is a place of entertainment for Prince Adipati Anom's family, and near the Bangsal Sriwedari, there is an open-air bathing pool.

Figure 6. Gate to Bangsal Sriwerdari (Source: Adianti, 2020)

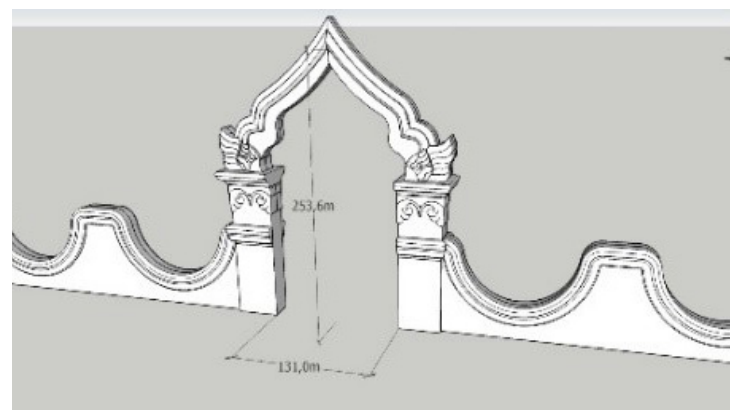

The back zone is the most private area, and the southernmost gate in this area is bordered by the middle zone. The gate is placed on the west and east sides with column-beam type and has a shutter or barrier (type III). Only in this regol that uses ornamentation in its domain, the ornament used is the head of time, bird, and animal head. When the head is interpreted as a reinforcement of reinforcements or a negative 
fuser, this decoration can be found in HinduBuddhist temples (figure 7) (Yunus $M$ et al., 2016). Kala comes from Indian mythology describing Siva's son, Kirtimukha, where because of his power, he was given the power to guard the entrance of the Mahakala Palace / Temple (Sumadi, 2016). Ornaments or various head ornaments when in traditional Javanese buildings are classified as ornamental fauna, where ornamental fauna functions as a repellent of evil and vengeance and courage. Regol placement with ornate barriers indicates that buildings in the rear zone area are sacred or deemed important, supported by an ornament type of fauna that is usually placed at the main entrance or sacred space (Cahyandari, 2017). In this area, there is the Prabayekso Ward building, which functions as the family room or the main bedroom of Prince Adipati Anom. Like the Prabayeksa Ward in the Royal Palace, the Prabayekso Ward in nDalem Mangkubumen can be interpreted as a very large beam of light (giant) and is a designation for the sun's source of life, which is very large (Wardoyo \& Sulaeman, 2017). Around the Proboyekso, there are small buildings to support the Proboyekso ward, which leads to the buildings around ndalem Proboyekso, which must pass through the gate. All gates in the rear zone are column type with a unified roof and use a shutter or barrier, except for the gate that leads to the backyard is only a column. The distance between the gate and the shutter varies between $1 \mathrm{~m}-3 \mathrm{~m}$, the distance between the gate and the shortest gate $1 \mathrm{~m}$ is located at the gate that leads to the bathroom. Changes in the distance between the gate and the shutter indicate more private space because of the limited people passing by.

Figure 7. Gate to Bangsal Proboyekso (Source: Adianti, 2020)

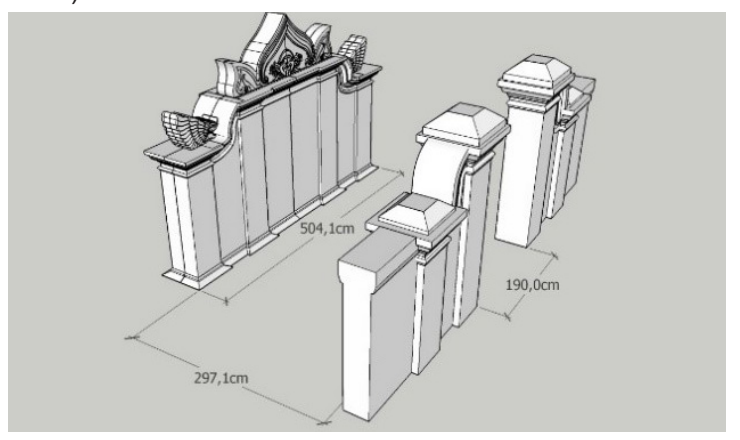

\section{CONCLUSION}

The main gate nDalem Mangkubumen has the largest dimensions and is placed on the border of the outer front zone with the outer zone. nDalem Mangkubumen Gate, which is placed on the boundary between zones totaling two is placed on the west-east side symmetrically, and the addition of ornament or decoration on the gate to show the zone is more private. Changes in the size of the circulation room are determined by the user, the more that passes through the gate, the wider size of the circulation room will be. In other words, the size of the circulation space can be a sign of who can pass through the gate. Buildings that are considered private then the existing gates around it have a shutter or barrier, while buildings that are used for public gates around it without using a shutter or barrier.

\section{REFERENCE}

Adianti, I. (2019). Tipologi tata ruang rumah bangsawan di dalam Baluwarti Kraton Yogyakarta, berdasarkan gelar kebangsawanan. JURNAL ARSITEKTUR PENDAPA, 2(1), 35-44.

Cahyandari, G. O. I. (2017). Tata Ruang Dan Elemen Arsitektur Pada Rumah Jawa Di Yogyakarta Sebagai Wujud Kategori Pola Aktivitas Dalam Rumah Tangga. Jurnal Arsitektur Komposisi, 10(2), 103.

Cahyandari, G. O. I., Pramudito, S., \& Wismarani, Y. B. (2019). Conservation Of Ndalem As Part Of Sustainability Efforts - Case Study: Ndalem Tedjokusuman. Atlantis Press.

Djono, Dkk, (2012), Nilai Kearifan Lokal Rumah Tradisonal Jawa, Humaniora Vol 24 No 3:269-278

Ikaputra, (1993), A Study On The 'Contextuality' Of The Palace Environment Case Study: Noble Residences And Its Magersari Land Right System In Yogyakarta, Indonesia. Unpublished Thesis. Department Of Environment Engineering Faculty Of Engineering Osaka University.

Kartono, (2005), Konsep Ruang Tradisional Jawa Dalam Konteks Budaya, Jurnal Dimensi Interior Vol 3 No 2:124-136.

Laksmi Kusuma Wardani. (2007). Perubahan Desain Rumah Tinggal Jawa Menjadi Ruang Publik Terbatas (Dari Rumah Bangsawan Ke Hunian Publik). Dimensi 
Interior, 5(2), 98-108.

Nur'aini R., \& Ikaputra, (2019), Teritorialitas Dalam Tinjauan IImu Arsitektur, INERSIA Vol 15(1), 12-22.

Sektiadi, (2015), Pendekatan Kawasan Dalam Pengelolaan Cagar Budaya, Kasus Njeron Beteng, Yogyakarta, Jurnal Widya Prabha Edisi Iv;24-36

Triady, (2012), Regol Pagar Rumah Tradisional Di Laweyan Surakarta, Simposium Nasional Rapi Xi Ft Ums

Umadi, S. (2016). Various Decorative Of Kala As An Ornamental Art Works. Ornamen. Jurnal Kriya Seni Isi Surakarta, Vol 8 No

Wardoyo C., Sulaeman A, (2017), Etnolinguistik Pada Penamaan Nama-Nama Bangunan Dikeraton Yogyakarta, Al-Tsaqafa: Jurnal IImiah Peradaban Islam, Vol 14 No 1;55-75

Wibowo, (1998), Arsitektur Tradisional Daerah Istimewa Yogyakarta, Jakarta:Departemen Pendidikan Dan Kebudayaan RI

Widayatsari S., (2002), Tata Ruang Rumah Bangsawan Yogyakarta, Jurnal Dimensi Teknik Arsitektur Vol. 30, No. 2: 122 - 132

Yuniastuti T. Wibowo S., (2010), Perubahan Bentuk Bangunan Dalem Mangkubumen Yogyakarta, Yogyakarta:Lpjj.

Yuniastuti, T., \& Murti, D. A. K. (2019). Pengaruh Perubahan Fungsi Bangunan Pada Bentuk Bangunan Bangsal Banjar Andhap Dalem Mangkubumen Yogyakarta. Jurnal Arsitektur Pendapa, 2(1), 20-34.

Yunus M, dkk, (2016) Fungsi Dan Makna KalaMakara Pada Bangunan Candi Di Jawa Masa Hindu Buddha, Retrieved from: https://www.studocu.com/id/u/4766492 